\title{
Inclusion of BUMDesa Tax Awareness with Mina Agrowisata in The Self-Assessment System
}

\author{
Asih Machfuzhoh ${ }^{1}$, Intan Puspanita ${ }^{2}$, Refi Pratiwi ${ }^{3}$ \\ 1,2,3 University of Sultan Ageng Tirtayasa, Indonesia \\ asih.machfuzhoh@untirta.ac.id
}

\begin{abstract}
Abstrak
Potensi unggulan yang dapat dikembangkan di desa yang kaya produk pertanian atau perkebunan adalah agrowisata desa. Agrowisata sangat potensial dikembangkan menjadi wisata unggulan dan tinggal dikembangkan menjadi sebuat tempat untuk para wisatawan berkunjung. Agrowisata juga dapat melibatkan banyak pemilik lahan dan masyarakat.

Selain sebagai penguatan ekononomi mandiri, harapan pemerintah adalah dengan kemandirian ekonomi yang dikelola BUmdesa, maka akan menjadi salah satu pemasukan negara, melalui pajak. Banyak yang belum paham, bagimana perlakuan perpajakan terhadap BUM DEs BUMDes merupakan entitas berbentuk badan usaha yang dibentuk dari kekayaan desa yang dipisahkan seperti halnya dengan BUMN dan BUMD.

Selama itu, kita ketahui bahwa program pemerintah tidak dikenakan pajak. Pendapatan dari suatu yayasan yang berasal dari sumbangan dan hibah bukan merupakan objek pajak. BUMDes memiliki kegiatan operasional yang mana dari kegiatan tersebut mampu menghasilkan keuntungan. Sehingga, BUMDes telah memenuhi syarat sebagai objek pajak. Oleh karena itu pengenaan pajak untuk BUMDes adalah pajak Badan.
\end{abstract}

Kata kunci: Bum Desa, Pemahaman, Keasadaran Pajak,

\begin{abstract}
Excellent potential that can be developed in villages rich in agricultural or plantation products is village agrotourism. Agrotourism has the potential to be developed into superior tourism and only needs to be developed into a place for tourists to visit. Agrotourism can also involve multiple land owners and communities.

Apart from strengthening the independent economy, the government's hope is that with economic independence managed by BUmdesa, it will become one of the state's income, through taxes. Many do not understand how the tax treatment of $B U M$ DES BUMDes is an entity in the form of a business entity formed from separated village assets as is the case with BUMN and BUMD.

During that time, we know that government programs are not taxed. Income from a foundation derived from donations and grants is not an object of taxation. BUMDes has operational activities which from these activities are able to generate profits. Thus, BUMDes has met the requirements as a tax object. Therefore, the tax imposition for BUMDes is corporate tax.
\end{abstract}

Keywords: Village Owned Enterprises, Understanding, Tax Awareness 


\section{Introduction}

Based on Law Number 6 of 2014, the issuance of Regulation of the Minister of Villages for Development of Disadvantaged Regions and Transmigration Number 4 of 2015 concerning the Establishment, Management, Management and Dissolution of Village-Owned Enterprises, is expected to encourage villages to manage existing resources in the village, including development the economy of the people. One way to manage the economy of rural communities is to form Village Owned Enterprises (BUMDes). BUMDes was formed with the aim of improving the welfare of local village communities, improving economic conditions and village original income, increasing efforts to manage village potential (human resources and natural resources) in accordance with the needs of rural communities and functioned to become the backbone of equitable distribution and village economic growth. Agunggunanto, 2016). BUMDes is a business entity originating from village assets which is separated to manage assets, services, and other businesses for the greatest welfare of the village community (Ihsan, 2018).

There are so many roles of BUMDes that can help develop Tourism Villages, therefore the government encourages villages to form BUMDes, especially those that have potential as tourist attractions. The business entity is prepared to manage village finances in accordance with the provisions of Law No. 6/2014 on Villages (UU Desa). Article 87 of the Village Law and Article 132 of PP No. 43/2014 explains that every village is given the same opportunity to establish BUMDes, although it is not something that is a forced obligation. The existence of BUMDes is undeniably bringing changes in the economic and social fields (Anggraeni, 2016)

This village entrepreneurship can be accommodated in Village Owned Enterprises (BUMDes) developed by the government and village communities (Prabowo, 2014). The establishment of BUMDes is based on the needs and potential of the village, as an effort to improve community welfare (Agus, et al. 2018).

BUMDes is an entity in the form of a business entity formed from separated village assets as is the case with BUMN and BUMD. Therefore, the tax imposition for BUMDes is corporate tax. As we know, the tax must meet 2 tax elements, namely the subject of corporate tax and the object of corporate tax (Kurnia, 2015). The subject of corporate tax referred to here is a group of people \& or capital which is a unit, both those who do business and those who do not do business including, Limited Liability Companies, Limited Liability Companies, BUMN, BUMD, BUMDes, Firms and so on. Meanwhile, the object of tax referred to in this case is any additional economic received or obtained by the Corporate Taxpayer, both from Indonesia and abroad, which can be used for consumption or to increase the wealth of the Corporate Taxpayer concerned by name and in any form. 2016).

During that time, we know that government programs are not taxed. However, if we understand the explanation of the tax object which can be interpreted as a transaction (usually a source of income) which according to tax regulations is classified as a transaction that must be taxed. Income from a foundation derived from donations and grants is not an object of taxation. BUMDes has operational activities which from these activities are able to generate profits. Thus, BUMDes has met the requirements as a tax object.

The Faculty of Economics and Business, has been accompanying the Cisaat Bamboo Village Tourism Village, Banyuresmi, Pandegelang. The Tourism Village also has a Joint Village BUM, which is a combination of several Bumdes around the Tourism Village that collaborate to advance this pioneering Tourism Village. BUM Desa Together with Mina Agro Tourism was established through the Inter-Village 
Mustawarah (MAD) which was attended by village heads, BPD leaders, community leaders, youth, entrepreneurship and other village delegates as well as invitations from DPMPD Pandegelang Regency, Regional Assistance and District Representatives. Labuan and Jiput. Produced: Joint regulations with the Labuan Village Head, Teluk Village Head, Caringin Village Head, Banyubiru Village Head, Jiput Village Head, Banyuresmi Village Head, Banyuresmi Village Head, Sukacai Village Head and Tenjohalang Village Head Number 011 of 2018, Number 007 of 2018, Number 08 of 2018, Number 002 of 2018, Number 03 of 2018, Number 010 of 2018, and Number 02 of 2018, Number 003 of 2018. Regarding cooperation between villages, the establishment of a Joint Village Owned Enterprise MINA AGRO WISATA and the establishment of a Joint Village Owned Enterprise MINA AGRO TOURISM.

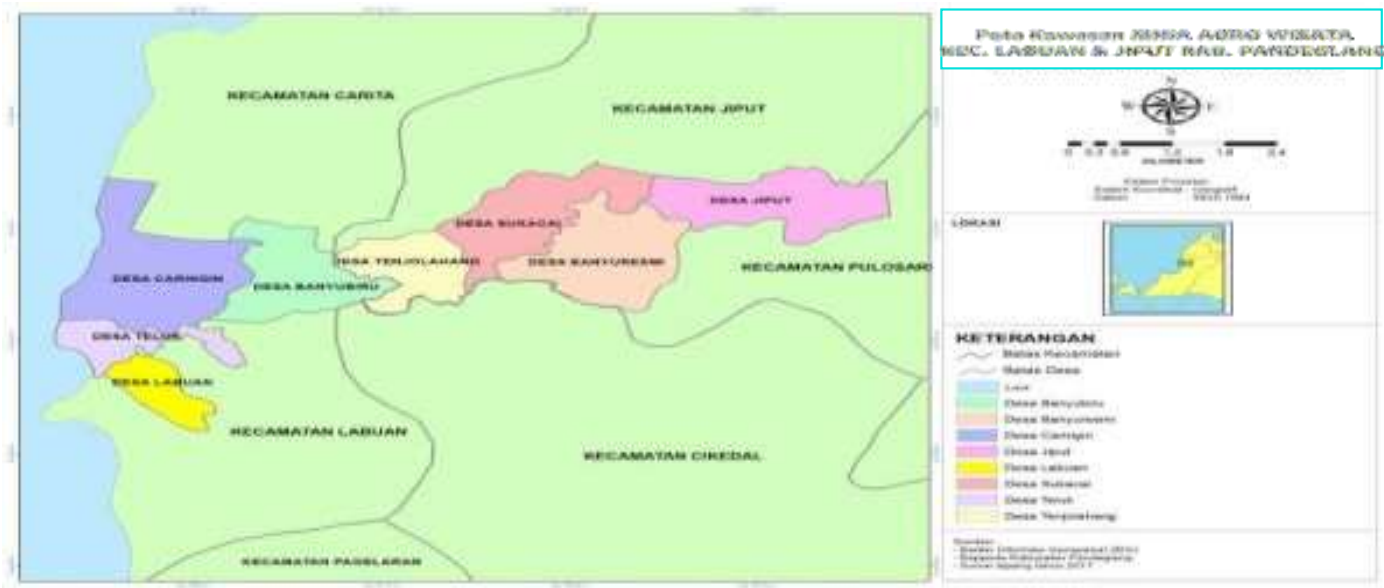

Figure 1. Location Map of the two Partners Area

\section{Implementation Method}

Bumdesa that will be partners in this service is Bumdesa with MINA AGRO TOURISM. The stages of the method in this service are carried out as follows:

1. Socialization of the role of Bumdesa in development participation, so that it is expected to increase awareness and knowledge of Bumdesa as its role as a taxpayer in state development through taxes, is the first stage to be carried out.

2. The second stage, namely the socialization of self-assessment from taxpayers in taxation for Bumdesa with the aim of increasing understanding and awareness of the Bumdesa tax, is the second stage that will be carried out.

The summary of the implementation methods that will be carried out in this activity are as follows:

Table 2. Implementation Method to be used

\begin{tabular}{lll}
\hline No. & Target & Implementation Methodology \\
\hline 1. & Building the mindset of BUM & Conducting socialization and education regarding \\
Desa actors regarding its & the role of BUmdesa in development, with the aim \\
role in development and the & of increasing awareness and knowledge of \\
importance of taxes for & BUmdesa service participants regarding the \\
Country & important role of taxes for state development.
\end{tabular}

Source : Processed data 


\section{Results and Discussion}

According to Darussalam (2019), tax inclusion is a crucial factor in Indonesia. As part of tax education, tax inclusion is considered an effective mechanism to build trust in the government while encouraging public participation in the tax system. The reasons for the importance of tax inclusion are: First, the level of tax compliance is still low in Indonesia. Second, the inclusion of relevant taxes in the self-assessment system. Third, tax inclusion as an anticipatory step in welcoming the demographic bonus.

Fourth, tax inclusion can be a long-term solution in ensuring worker tax compliance in the non-standard sector which is starting to bloom today. Fifth, tax education is one of the four basic elements of guaranteeing an ideal tax system and meeting people's expectations. Sixth, tax inclusion stimulates the interest of Indonesia's young generation to become superior human resources in the tax sector. Seventh, tax inclusion is an integral part of the tax reform momentum. The success of Indonesia's 2017-2020 tax reform agenda aimed at optimizing tax revenues,

Socialization regarding the role of BUM Desa Bersama in development is the beginning of this service activity, so it is hoped that it can increase awareness and knowledge of BUM Desa Bersama about its role as a taxpayer who indirectly participates in state development. In addition to increasing awareness of its role in development, with this socialization activity, it is hoped that it will also increase awareness of the bumdesa together to pay taxes and the knowledge that the tax benefits obtained are beneficial for the bumdesa together.
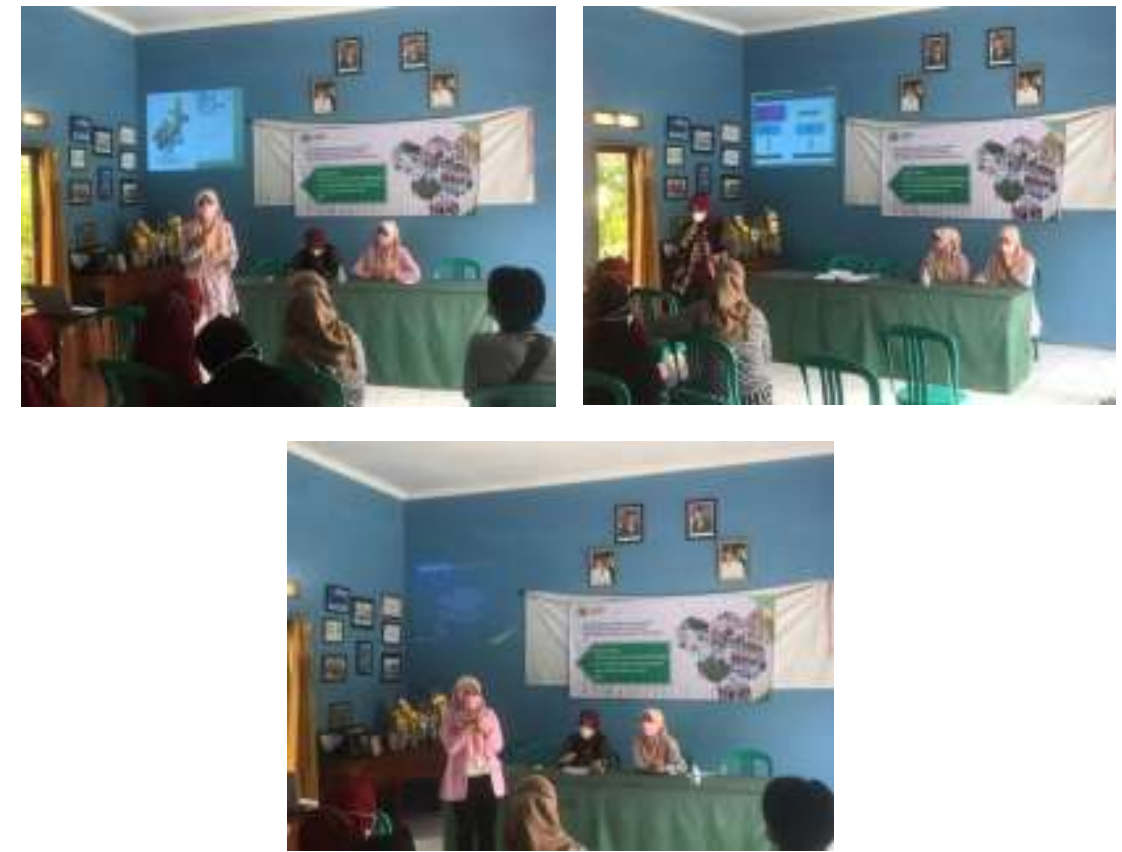

Figure 2. Socialization of the Role of BUM Desa Together for Development

In this service, it was also explained that our tax collection system is selfassessment. Where this collection system requires taxpayers to calculate, pay, and report taxes owed according to the provisions. Therefore, the determination of the amount of tax owed is entrusted to the taxpayer himself through the Tax Return (SPT) document which is submitted in person, online, postal or through other media.

According to the explanation of the Law on General Provisions and Tax Procedures (UU KUP), self-assessment is a feature and pattern of the tax collection system in 
Indonesia. This system gives trust and responsibility to taxpayers to take the initiative to register themselves to get a Taxpayer Identification Number (NPWP), and take care of their own tax affairs.

Because it has been entrusted to the taxpayer, the amount of tax owed does not depend on the existence of a tax assessment. The issuance of a tax assessment letter is only limited to certain taxpayers due to incorrect filling in the SPT or because the tax office finds fiscal data that is not reported by the taxpayer.

The legal basis for self-assessment is regulated in Article 12 paragraph (1) of the KUP Law which states "Every taxpayer is obliged to pay the tax owed in accordance with the provisions of the tax laws and regulations, without relying on the existence of a tax assessment letter." In other words, this system is more likely to focus on the active role of taxpayers in tax collection.

In this training activity, the BUM Desa Bersama participants were very enthusiastic because there were still some BUM Desa who did not understand about taxation. Several important findings were found in community service activities for BUM Desa Bersama, namely:

1. BUM Desa Bersama has not performed complete financial records and there are still those who do not understand how to record their financial statements.

2. There are still BUM Desa who are confused about how to make NPWP due to limited information regarding what conditions are needed in making the NPWP.

3. BUM Desa Bersama are still confused about how to calculate their tax reporting funds because they do not understand and their business turnover is still very minimal so they still have not reported taxes.

This activity also informs business actors and BUM Desa Bersama that during the COVID-19 pandemic, taxpayers will receive incentives from the government regarding their business tax exemption. Micro, small and medium enterprises who wish to take advantage of this incentive only need to submit a realization report. With various problems related to taxpayers' tax obligations, this service in the form of training is very important to do, so that taxpayers avoid tax sanctions, encourage taxpayer compliance so that state revenues from the tax sector can increase.

\section{Conclusion}

This service activity aims to provide training and assistance for BUM Desa Bersama by providing an understanding of the basic concepts of taxation, how to calculate, pay and convey their tax obligations. The conclusions of this community service activity are:

1. This service activity can increase knowledge about the role of BUM Desa Bersama in development.

2. This service activity can increase the knowledge of BUM Desa Bersama actors regarding the benefits of NPWP, the reasons for BUM Desa Bersama actors having to pay taxes, as well as tax benefits. This service activity found the reason BUM Desa Bersama did not make an NPWP because it did not know how to make it and limited information regarding what conditions were needed in making the NPWP.

3. This service activity also found that the BUM Desa Bersama actors had not done complete financial records and there were still those who did not understand how to record their financial statements.

4. This service activity found that the BUM Desa Bersama actors were still confused about how to calculate their tax reporting funds because they did not understand how to calculate and report it and argued that their business turnover was still very minimal so they still did not report the BUM Desa Bersama tax. 


\section{Acknowledgment}

Thanks to the Community Service Team (PKM) to the Faculty of Economics and Business, , Tax Center Sultan Ageng Tirtaysa University for supporting all needs and facilitating in carrying out this community service. In addition, I would also like to thank the Village-Owned Enterprises Together with MINA AGRO WISATA for being willing to be partners in community service activities.

\section{Reference}

Agunggunanto, E. Y. (2016). Pengembangan Desa Mandiri Melalui Pengelolaan Badan Usaha Milik Desa (BUMDes). Jurnal Dinamika Ekonomi dan Bisnis, 6781.

Agus Taufik Hidayah, A. T., Pujiati, L., Hidyati, N., Hendrawan, S. A., Suprapto, S., \& Ali, N. (2018). Pendampingan Penyusunan Laporan Keuangan Pada Badan Usaha Milik Desa (Bumdes) Lestari Desa Bandung Kecamatan Diwek Jombang. Journal of community service, 2, 15-20.

Anggraeni, M. R. (2016). Peranan Badan Usaha Milik Desa (BUMDes) Pada Kesejahteraan Masyarakat Pedesaan. Modus Journal, 28(2),155-167.

Ihsan, A. N. (2018). Analisis Pengelolaan Badan Usaha Milik Desa ( BUMDes ) Gerbang Lentera Sebagai Penggerak Desa Wisata Lerep. Journal of Politic and Government Studies. 7(11).

Kurnia, Dadang. (2015). Pengawalan Akuntabilitas Pengelolaan Keuangan Desa. BPKP. Jakarta.

Mardiasmo. (2009). Akuntansi Sektor Publik. Jakarta: CV Andi Offset.

Mardiasmo. 2016. Perpajakan Edisi Terbaru Tahun 2016. Yogyakarta: Andi Offset.

Nordiawan, Deddi, Iswahyudi Sondi Putra, dan Maulidah Rahmawati. (2009). Akuntansi Pemerintahan. Yogyakarta: Salemba Empat.

Prabowo, T.H.E. (2014). Developing BUMDes (Village-owned Enterprise) for Sustainable Poverty Alleviation Model Village Community Study in BleberanGunung Kidullndonesia. World Applied Sciences Journal 30 (Innovation Challenges in Multidiciplinary Research \& Practice): 19-26.

Undang-Undang Republik Indonesia Nomor 6 Tahun 2014 Tentang Desa. 